reporting cases of infectious disease in his family, the doctor alone is held so by the sanitary authorities. The obvious reason of this is that technical knowledge and skill is needed to diagnose a case of infectious disease, which even the law cannot presume is possessed by the parent. Such a difficulty does not arise under the Notification of Births Act. Then, even after a case has been declared to be a notifiable diseuse by the medical attendant, the authority does not require a duplicate certificate from the parent, because this is entirely unnecessary, and if the medical man fails to report the case he alone is proceeded against.

I hold, therefore, if the procedure obtaining under the Notification Act is reversed in the administration of this Act and the parent is held responsible, as he ought to be, the objections of the medical profession to the Act must be greatly mitigated, though of course they cannot be completely removed, apart from an amendment of the Act. I quite think the above method will be the simpler way of administering the Act, because the first intimation to the medical officer of health of a non-notified birth will no doubt be received from the Registrar of Births and Deaths in his weekly returns. The certificate of the Registrar would be sufficient evidence against the parent to convict, and most readily obtained. Whereas if the local authority decided to proceed against some other person rather than the parent-for example, the doctor-inquiries would have to be set in motion to find out who was actually in attendance at the birth. Such attendance would have to be proved in court, \&c., and altogether the process would be a much more complicated one than that suggested above. I think, therefore, on the score of both convenience and simplicity the parent will be made responsible. Should this be the case the doctor could further protect himself in any case by drawing the attention of the parent to his obligation under the Act. I am, Sirs, yours faithfully,

Halifax, Dec. 23rd, 1907. JAS. 'T NEECH, M.D. Durh.,

$$
\text { teal Omcer of Health of.Halliax. }
$$

\section{ALCOHOLISM: ITS CAUSES AND TREAT- MENT.}

To the Editors of THE LANCET.

Sins, - There is a Chinese proverb to the effect- "It is not the wine that makes the drunkard but the vice"-i.e., "It is not a vice to drink wine but to be unable to resist the craving for it." This "craving" may be caused: 1. By inheritance-a fertile cause-from ancestors not necessarily alcoholic but whose nervous systems have been depraved by vicious excitement and self-indulgence. 2. Excessive and exhausting toil, either physical or mental (worry), monotonous work under the depressing influences of wet and cold, foul air, unwholesome or scanty food, squalor, and dirt. 3. The ennui owing to want of occupation, which is often the inheritance of those who have not to earn their daily bread by any physical or mental effort and who find in alcohol enthanasia.

\section{"The rich man's son inherits wants, \\ His stomach craves for dainty fare, \\ With sated heart he hears the pants \\ And win}

"Under-work," then, is a fertile cause of alcoholism. 4. The powerful influence of environment in the association with those who have acquired the alcoholic habit. As an instance of the effect of example, many years ago, on a voyage to India, when the rum ration was issued daily to soldiers on board a transport, I watched the recruits at the rum tub. Some of these lads had apparently never tasted raw spirits before they came aboard. At first they made a wry face over their "tots" and swallowed their liquor with difficulty. Towards the end of the voyage no difference was discernible in the apparent relish with which the rum: ration was gulped down by the recruit and by the older soldier. These are the chief causes of the drink habit. "Train an idea, acquire a babit, obtain a master," is perhaps more applicable to alcoholism than to anything else. Once the alcoholic habit is acquired the power of resistance is gradually enfeebled until all self-control is lost and the craving for drink becomes an over-mastering passion.

As regards others, the drunkard's action takes effect more especially in the procreation of children whose nervous systems are more or less depraved or morbid, and who are often truly "degenerate," who revert to the animal type of human kind, the tiger ape of Voltaire, the human beasts of Schopenhauer and Zola. An old French physician, Heulard d'Arcy, translates a speech of Diogenes to a petit arevé of that period as follows: "Jeune fils, mon amy, ton père t'a engendré estant yvre" (ivre). "My young friend, thy father, when drunk, begat thee." And the same observation might be made to many a youngster of the present age. This nervous depravity may take various forms and our prisons and asylums teem with the children of alcoholism, who will live, and who will not or cannot justify their existence by doing any useful work, who prey upon the humanity which helps them. The prevention of alcoholism might be helped by a better instruction in the public schools on the use of alcoholic beverages and the misery and suffering which follow in the train of the drink habit. Our youth should be taught that, although it may be contrary to the example of parents, the habitual absorption of alcoholic beverages is neither necessary nor beneficial for any ordinary man doing man's work, physical or intellectual, much less for any ordinary woman; that alcohol in the shape of wine, beer, cider should be looked on as a pleasant luxury, as an aid to social intercourse, not as a necessary article of daily consumption ; that alcohol may be necessary in certain circumstances, but these are so rare that probably the majority of persons may go though life without this necessity ever arising; that those who cannot do without alcoholic drink for the most part have either acquired a babit which has obtained a mastery over them or they are "poor creatures" who require a fillip to do their daily work with satisfaction to themselves and to others. Lastly, it should be strongly impressed upon the young and inexperienced that while an occasional glass of beer, claret, or cider may be indulged in by the young, distilled spirits should never find a place amongst their beverages. To youthful blood and brains they are abhorrent-destructive as vitriol to steel. Hogarth's contrasting pictures, Beer Street and Gin Lane, illustrate a moral and physiological lesson.

To reform the inebriate habit is confessedly very difficult; indeed, some assert that it is almost impossible to cure a confirmed drunkard, especially one of the female sex. Our first aim should be to get if possible the coöperation and the confidence of the patient in the early stage of alcoholism. The personal influence of the priest, of the physician, of the father or mother, husband or wife, should be brought to bear to try to induce the victim of the alcoholic habit to reform. This influence must be used judiciously and with discretion, especially in the case of the wife, for the "nagging wife" often aggravates the evil which the poor woman, with the best intentions, would cure. Removal from environment and associates is all important; " country homes," or " houses of rest" should be multiplied in which a few patients can be treated, and the influence of the master of the house should be exerted to try to induce by example as well as by advice the patients to reform by work of some sort, agriculture or horticulture; the care of small stock might be given; any one can work on a small holding (though very few can make a living out of it) and the work can be made as light or as energetic as the worker pleases. Of course, no alcoholio drink should be obtainable in these institations, but it is useless to cut off the supply of liquor unless some occupation be given to divert the mind of the patient from the craving for alcohol. Drugs are useless, worse than useless, except perhaps some simple sedative, such as bromide in some form, as they are apt to lead the patient to rely on the drug and promote a vain hope that self-help may not be so essential as has been represented. The diet should be as simple as possible. Alcoholics usually have a depraved stomach and a palate which craves for hot and stimulating food, and a little starvation diet, or what would be considered such, may be necessary.

The punitive method of treating alcoholism is useless; I have seen it tried in the Army more or less during 30 years of my life. Fines, confinement to barracks, cells, imprisonment, and in the old days flogging-all failed to check the propensity to obfuscate the system with the alcoholic poison. Those who were subjected to it, with rare exceptions, usually went from bad to worse unless they got into the habit of soaking without showing it, and often obtained a character for sobriety and badges for good conduct which they certainly did not deserve, if abstinence was considered a sine $q u \hat{a}$ non. As to the advanced cases of confirmed alcoholism who are in many cases hopeless, who are 
mere cumberers of the earth, who beget children diseased and degenerate, who are confined in the hospital of the Bicêtre at Paris, or, less fortunate, spawned upon the community and at large,-these should be segregated-the sexes separate-on an island, if possible, where no drink can be obtained and on which no visitor or boat should be allowed to land without a permit. Work, agricultural or other, ought to be provided. These inebriates should be divided into classes according to their degree of depravity and a long period of probation should be enforced before they return to the outside world. For the hopelessly depraved, the irreclaimables, the human animals to which $I$ have already alluded, there is but one remedy-" sterilisation"; but 'tis the daydream of a visionary reformer-

"They all refused to listen: quoth they, 'We bide our time,'

And the bidders seized the children, poverty, filth, and crime.

And the prisons teemed with victims, and the gallows soarea on high, And the foul abominations rose reeking to the sky."

$$
\text { I am, Sirs, yours faithfully, }
$$

C. M. Douglas,

Dec. 18th, 1907 Lieutenant-Colonel, A.M.S. (retired)

* * We regret that we have been compelled to abridge this letter from considerations of space.-ED. L.

\section{THE REFORM OF THE ROYAL COLLEGE OF SURGEONS OF ENGLAND. \\ To the Editors of THE LANCET.}

Sirs,--In the last annual report of the Royal College of Surgeons of England we were favoured with the personal views of some individual members of the Council, and a good deal of capital seems to have been made at the expense of the absent Members of our College by reference to the academic and scientific attainments of the members of the Council.

Now, Sirs, I should like to ask a few questions, with your kind permission, and I would venture to ask for answers from your numerous readers who are better informed on these points than I am. What are the superior academic and scientific attainments of the Council? Are there not any Members of the College who have obtained degrees in science from our older universities or who have attained any academic position at all? Have the members of the Council of the College absorbed or inherited all the academic and scientific attainments of the surgical world? If so, what about the scientific instruments in everyday use in general practice, such as the stethoscope, the ophthalmoscope, the laryngoscope, the vesicoscope, the sphygmograph, and what about anæsthetics and germs ?

When one considers the immense amount of clerical, clinical, chemical, and general assistance of a practical and scientific character the so.called leaders in medicine and surgery have received, and are daily receiving, often at the hands of their junicrs, is it not matter for surprise, and even of regret, to see so small an amount of original work turned out by these leaders?

What has the Council done for its Members? Did it not support a movement to extinguish the Society of Apothecaries and thereby would have deprived many of its own Members practically of their only medical qualification? Has it not practically raised the fees for the Membership without the consent of the Members? Has it not supported a Bill for the registration of midwives and thus created a lower order of practitioners to compete with its own Members after selling them a diploma and guaranteeing to protect the purchasers "in the exercise and enjoy. ment," \&c.? Is it not at the present moment supporting a measure providing for the admission of women to the Membership of the College and at the same time preventing them from becoming Fellows? If this is not legislation in favour of the Fellows and against the Members I do not know what is.

Women have never entered any profession or calling in life but what they have succeeded in lowering the fees derivable therefrom. When they first entered our profession they said they wished to go to help their suffering sisters out in India. They show their eagerness to do so now by practising as the medical and surgical hacks of societies trading in medicine and surgery as so-called "medical missions" under the rgis of the Universities of Oxford and Cambridge at fees as low as $2 \pi$. and $1 d$. for the cork. Could not the Council of our College send a strongly worded letter of remonstrance to the universities concerned requesting these scientific and academic bodies to put a stop to these practices. I am, Sirs, yours faithfully,

Putney, S.W., Dec. 16th, 1907.

A. S. MORTON.

\section{NOTES UPON HEALTH RESORTS.}

\section{JAMAICA AS A HEALTH RESORT.}

(By our Special Commissioner.)

$$
\text { V.1 }
$$

The FoOD-SUPPLY.-SANitation.-Mode of LIFE AND Dress.-The Public Heal'Th. - The ReIative ADVANTAGES OF JAMAICA AS A HEALTH RESORT.

\section{The Food-supply.}

THE quality and cooking of the food in the Jamaican hotels and lodging-houses afford a frequent cause of complaint to visitors and in many instances this complaint is justified. There is no reason whatever why it should be. Jamaica produces a great variety of most excellent food and if this is prepared by a good native cook on an open wood fire as appetising a dinner may be enjoyed as the veriest epicure can desire. Too often, however, the hotel-keeper attempts to meet the guest's supposed prejudices by supplying a very poor imitation of English fare, and a wearisome procession of tough chickens at dinner followed by coarse ham and small but good eggs at breakfast forms the staple of those important meals. They are largely redeemed by the excellent fish, such as the king-fish, callipeva, mountain mullet; and Jamaica produces equally good beef and mutton; if the joints are kept on ice until the rigor mortis has passed off and thawed before cooking they are tender and toothsome, but when they are cooked within a few hours of the onset of the rigor, as is often done, they are tough and tasteless. The game birds, pigeons of various sorts and wild duck, are capital eating, and oysters (which grow on mangrove trees in brackish water) and turtle soup are regular Jamaican dishes. The bread is almost. always good, being well made from fine wheat flour, the cassava cakes are excellent, and the native vegetables form a great part of the daily dietary; they are of great variety, including several kinds of yams, yampis, bread-fruit, sweet potatoes, plantains, and the delicious avocado pears -the "midshipmen's butter" of our grandfathers-and many other roots and fruits which are far nicer than the anæmic lettuces and stringy beans with which the English visitor is too often confronted. Jamaica does, however produce good cabbages and excellent potatoes. A word must. be said about the akké. Akké (with salt fish) is a great Jamaica dish, but many people are deterred from trying it on account of various cases of poisoning that have followed its ingestion; the fruit when unripe contains hydrocyanic acid but in its proper condition is quite safe and extremely palatable. As to sweet fruits, Jamaica. is one of the earth's fruit gardens; her citrous fruits, oranges, grape fruit, and shaddock are probably unequalled, certainly unsurpassed. There are several fine varieties of pine-apples, bananas have become almost the chief plank in her commercial platform, mangoes of many varieties grow in infinite abundance, and there is abundance of other tropical fruit which the visitor will soon enough find out for himself. The persimmon is grown but it is a pity that the delicate mangosteen, so highly esteemed in the Fast Indies, has not obtained a foothold on the island; granadillas and passion fruit can often be obtained. In the hills English fruit such as strawberries and even apples are grown, and in a garden 4000 feet up in the Blue Mountains I saw an orange tree and apple tree, each in fruit, standing next to each other, an excellent symbol of the varied fecundity of Jamaica's vegetation. The country produces excellent condiments, such as red peppers, chillis, \&c., and the delicious guava jelly has a wide reputation in England. The dairy produce is not at all what it might be, as the pen-keepers find it pays to fatten cattle

I Nos. I.. II., III., and IV. were published in THE LANCET of Oct.5th (p. 985 ) and 26 th (p. 1193), Nov. 16th (p. 1421), and Dec. 7th (p. 1646), 1907,
respectively. 